\title{
Leaf Traits and Aboveground Biomass Variability of Forest Understory Herbaceous Plant Species
}

\author{
Sonia Paź-Dyderska, ${ }^{1,2} \odot$ Marcin K. Dyderski, ${ }^{2} \odot$ Piotr Szwaczka, ${ }^{1}$ \\ Marta Brzezicha, ${ }^{1}$ Karolina Bigos, ${ }^{1}$ and Andrzej M. Jagodziński ${ }^{1,2 *} \odot$
}

${ }^{1}$ Department of Game Management and Forest Protection, Faculty of Forestry, Poznań University of Life Sciences, Wojska Polskiego 71c, 60-625 Poznań, Poland; ${ }^{2}$ Institute of Dendrology, Polish Academy of Sciences, Parkowa 5, 62-035 Kórnik, Poland

\begin{abstract}
Despite increasing use of trait-based approaches in community ecology, most studies do not account for intraspecific variability of functional traits. Although numerous studies investigated functional traits of species with high economic value, the intraspecific and interspecific (caused by species identity) trait variability of forest understory herbs is still poorly understood. We aimed to assess the variability of specific leaf area (SLA), total leaf area, aboveground biomass and leaf mass fraction among 167 forest understory plant species, and the level of variability explained by species identity and collection site. We hypothesized that the level of intraspecific variability of SLA is underestimated in commonly used trait databases and that the interspecific variability (caused by species identity) is greater than intraspecific variability (site-specific). Our study revealed higher interspecific than intraspecific variability of the traits studied. We also confirmed that
\end{abstract}

Received 14 February 2019; accepted 4 July 2019;

published online 31 July 2019

Electronic supplementary material: The online version of this article (https://doi.org/10.1007/s10021-019-00421-6) contains supplementary material, which is available to authorized users.

Author's Contribution AMJ and MKD conceived the ideas and designed methodology; KB, MB, SPD and PS collected the data; SPD and MKD analyzed the data; SPD led writing of the manuscript with substantial input of MKD and AMJ. All authors contributed critically to the drafts and gave final approval for publication.

*Corresponding author; e-mail: amj@man.poznan.pl level of intraspecific variability available in the LEDA database is underestimated. We confirmed that species identity was the main factor determining the values of all the traits studied, and site-specific random effects explained lower amounts of variation in traits. Use of trait values from databases not acknowledging intraspecific variability is biased by uncertainty about this variability. For that reason, our analysis used mean trait values to reduce uncertainty of the results in the study conducted to assess human impacts on ecosystems. Thus, our study might support the assumption that level of intraspecific variability of functional traits is lower than interspecific variability.

Key words: biomass allocation; functional traits; herb species; interspecific variation; intraspecific variation; leaf economic spectrum; leaf mass fraction; life strategies.

\section{HighLIGHTS}

- We studied leaf traits and aboveground biomass of 167 herbaceous species.

- We quantified intraspecific and interspecific trait variability. 
- The use of mean trait values is not highly biased by site-specific factors.

\section{INTRODUCTION}

Revealing the effects of plant diversity and interspecific interactions on related ecosystem functions is a challenging task needed to guide conservation efforts and management of ecological resources (Chapin III and others 2000; Díaz and Cabido 2001). However, the immense number of species and their broad ranges of occurrence make collection of the appropriate amount of data difficult due to the time, labor and money needed for fieldwork (Wilson and others 1999). One of the possible solutions is the use of functional traits, as numerous databases are being developed worldwide. Functional traits are morphological, physiological and phenological features influencing the growth, reproduction and survival of species and populations (Violle and others 2007). The most useful functional traits for running analyses and showing strong correlations with other parameters are mainly specific leaf area (SLA), total leaf area, the amount of nitrogen in leaves, seed mass and plant height (Díaz and others 2016). For example, SLA is crucial for quantifying analyses of life strategies of plants (Westoby 1998; Wilson and others 1999) and for assessing the productivity of ecosystems (Smart and others 2017; Ivanova and others 2018). Total leaf area, as well as other traits, for example, seasonality of foliage or canopy structure, may contribute to an explanation of the variability of aboveground biomass in a grassland ecosystem (Schumacher and Roscher 2009). Aboveground biomass can be used as a proxy for plant responses to harsh conditions in high altitudes (Ma and others 2010). Similarly, leaf mass fraction and other traits connected to biomass allocation may reflect important trade-offs and allometric relationships in plant functioning (Kleyer and others 2019; Poorter and others 2015). The recognition and understanding of correlations between those traits provide the ability to assess plant responses to climate change, or to estimate the possible shifts in species ranges, and their potential threats or invasiveness (Ordonez 2014; Canessa and others 2018; Wuest and others 2018). The achievement of this goal is crucial in the context of predicting the impact of global climatic change on the shape, functioning and diversity of the Earth's ecosystems. Moreover, the advantages of trait-based approaches for ecological studies and biomonitoring in comparison with traditional taxonomic approaches are highly significant, as it meets the general need for better inter-taxon and inter-region comparability (Reich and others 1998a; Cornwell and others 2008; Freschet and others 2011). It is particularly important for developing countries, where funding for research is often extremely limited, but where the adverse effects of human activity on the environment are the largest (Schmidhuber and Tubiello 2007; Müller and others 2011).

Most studies prove that SLA shows significant diversity among species and is driven by species identity (Westoby 1998; Poorter and De Jong 1999; Dyderski and others 2016; Kwon and others 2016). On the other hand, the impact of other factors (for example, temperature, precipitation and seasonal dynamics of light availability) on the variability of plant traits has also been highlighted (Hernández-Calderón and others 2014; Popović and others 2016; Blonder and others 2018). For that reason, some researchers decide to measure the trait values directly, taking environmental variability into consideration, although this is only possible when examining small- or medium-sized areas (Ma and others 2010; Carlos and Rossatto 2017; McCoy-Sulentic and others 2017; Taylor and others 2018). Yet, in the face of imperfections of currently used methods, it is crucial to examine the characteristics of plant variability and the amount of variance explained by different factors, so that we can use them in further research, while being conscious of their shortcomings and advantages.

This issue has been investigated across different habitats, always indicating the importance of study scale-the more extensive the study area, the less important the intraspecific variability (Albert and others 2011). In our study, we have adopted forest types from the Polish system of forest management divided into four ecological categories of habitats (fresh deciduous, wet deciduous, fresh coniferous, wet coniferous). On the other hand, in places where diversity is low, intraspecific trait variability gains much more importance, even in vast study areas, for example, the tundra biome (Bjorkman and others 2018). Moreover, recently the importance of intraspecific variability has been highlighted as a significant driver of diversity (Violle and others 2012). However, the general pattern shows that the contribution of interspecific variation to species responses is higher than intraspecific, for example in alpine and subalpine species (Kichenin and others 2013). However, intraspecific variability is less well represented in current databases of plants functional traits than interspecific variability. 
Poorer representation of intraspecific than interspecific variability results from the aim of numerous surveys of functional traits, which intended to provide a fast and inexpensive method of data collection about numerous taxa. Extensive datasets obtained using those methods have enabled an easy assessment of defined plant features, for example based on allometric models (Enquist and Niklas 2002; Weiner 2004; Poorter and others 2012, 2015). Recent studies compiled extensive datasets and aimed to explain relationships among traits shaping economic spectra of plants (Díaz and others 2016). Such relationships allow to conclude about numerous species traits, based on measurement of fewer traits (Reich and others 1998b; Westoby 1998; Peeters 2002; Maréchaux and others 2018). Therefore, the complexity and cost of conducting a study of variability of plants has diminished substantially (Czortek and others 2018; Stevens and others 2018).

The use of datasets in scientific research implies, however, an undefined level of uncertainty resulting from variability of traits among different habitat conditions. For example, in the LEDA database (Kleyer and others 2008) mean values provided for species are often based on measurements of few individuals. In contrast, the Bien database (Enquist and others 2016) is composed of individual plant measurements with (usually) data about collection site coordinates. However, this database covers mainly North and South American species, and for Europe it provides data from LEDA (Kleyer and others 2008).

Whereas surveys of woody species of high economic value have been realized worldwide (Poorter and Remkes 1990; Hunt and Cornelissen 1997; Ketterings and others 2001; Segura and Kanninen 2005; Peichl and Arain 2007; Jagodziński and others 2018), our knowledge about species of lower economic importance, mainly herbaceous species, remains low, and the topic has received relatively little attention. Forest understory species, although accounting for comparatively low shares of total forest ecosystem biomass, show up to 20-fold higher shares of micro- and macroelement cycling (Gilliam 2007; Muller 2014). Nevertheless, herbaceous forest species have been examined to a lesser degree than woody vegetation and even other herbaceous plants. Although other functional groups and habitats have been examined in that context, collection site has never been used as a random effect. Furthermore, the contribution of both species identity and collection site to variability of functional traits has never been quanti- fied; only the general pattern has been described (Cordlandwehr and others 2013).

Although plant functional traits have been measured worldwide (Castro-Díez and others 2011; Pierce and others 2013; Díaz and others 2016; Jagodziński and others 2016), the proportion of their variability explained by collection site is still poorly understood. Improving our knowledge of functional trait variation is a key goal in the context of inferring results for taxa not studied directly, and for using mean values from databases in broader studies concerning functional diversity of vegetation (Rudner and Gross 2012; Czortek and others 2018; Stevens and others 2018). Thus, the aims of this study were to (1) assess the variability of SLA, total leaf area, aboveground biomass and leaf mass fraction among forest understory plant species, (2) to compare SLA obtained from the most widely used LEDA database (Kleyer and others 2008) with field measurements from our study, and (3) to assess the level of variability in all four traits studied, explained by species identity and collection site. We hypothesized that (1) due to our poor recognition of forest understory herbaceous species ecology, the level of intraspecific variability of SLA is underestimated in commonly used trait databases and that (2) the interspecific variability (caused by species identity) is greater than intraspecific variability (site-specific).

\section{Materials ANd Methods}

\section{Methods}

The study was conducted in randomly selected forest collection sites in Poland and Czechia. Authors of the study collected plants during their travels connected with study and work, with no assumptions about dataset assembly and species selection. The only requirement was to collect specimens in the forest, i.e., under the canopy of at least a group of trees. The study area represents a climate transitional between maritime and continental. The geographical range of the collection sites studied varied from $49.1338^{\circ} \mathrm{N}$ to $54.0412^{\circ} \mathrm{N}$ and from $14.7423^{\circ} \mathrm{E}$ to $22.7273^{\circ} \mathrm{E}$ (Figure 1). Our plots represented mainly lowlands and highlands (elevation range $20-763 \mathrm{~m}$ a.s.l., with $75 \%$ of observations below $206 \mathrm{~m}$ a.s.l.). The collection sites were located in both deciduous and coniferous forests. The mean annual temperature in 19912010 was $8.07{ }^{\circ} \mathrm{C}$, and mean annual precipitation was $658.28 \mathrm{~mm}$ (GUS 2017). We studied 167 species from 112 genera and 40 families of herbaceous plants growing in various environmental condi- 


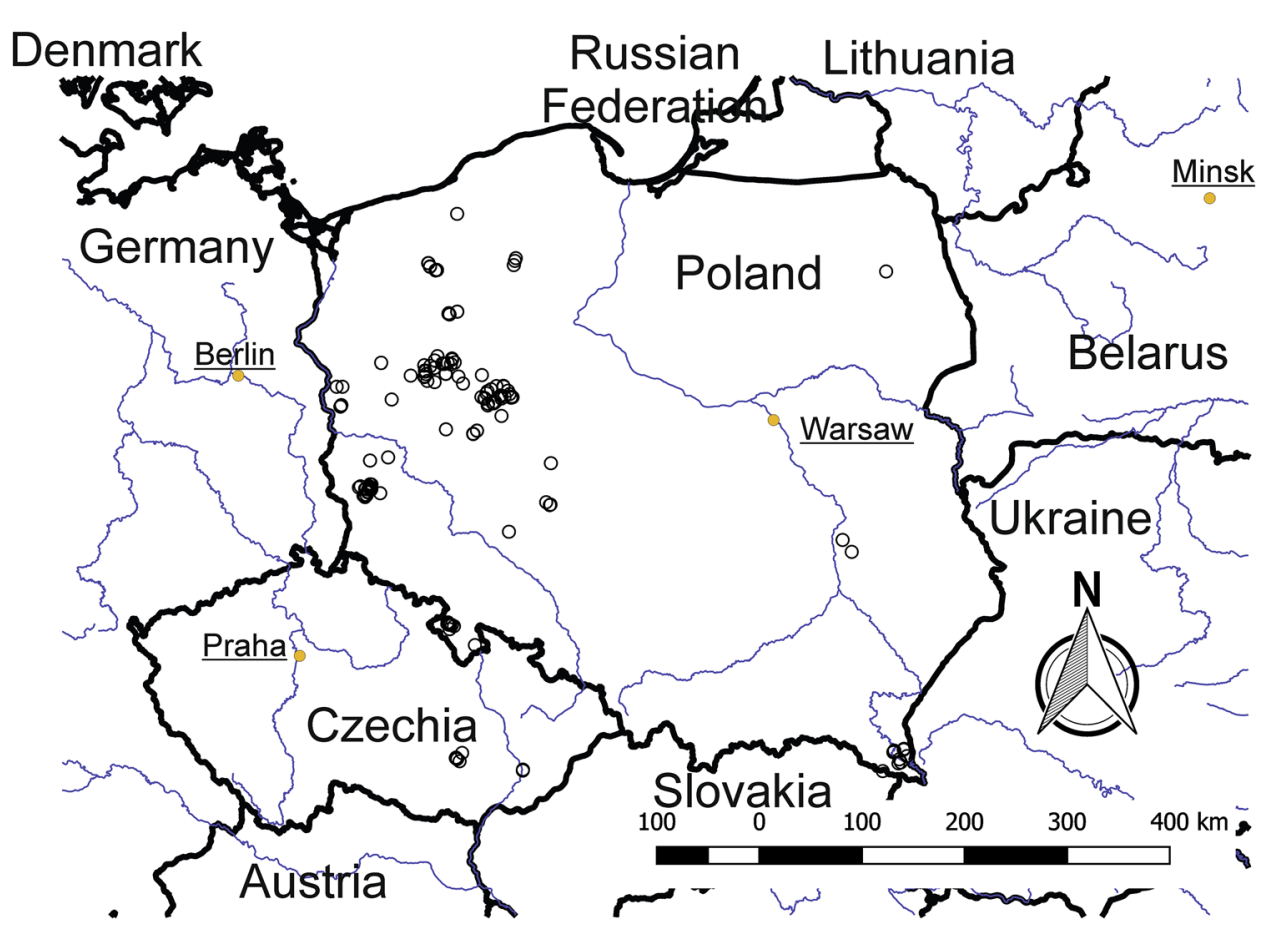

Figure 1. Distribution of the collection sites in Poland and Czechia (open dots). Also there are shown state borders (thick black lines), capitals (points and underlined names) and main rivers (blue lines) (Color figure online).

tions (Table S1). Our study covered species typical not only for forest ecosystems but also for meadows, forest edges and species without preferences to certain ecosystems types. However, all plants were collected from forests.

Field work was conducted in 275 locations throughout both countries and led to collection of 6543 individual plants. Plants were harvested during two growing seasons, from May 27, 2016, to September 5, 2017. We collected material during two growing seasons in order to collect more specimens. We are conscious of that different growing seasons could have an influence on the traits studied, as traits are climate-dependent (Gilliam 2007; Jagodziński and others 2016; Blonder and others 2018). However, on our collection sites there were no extreme weather events such as droughts, fires or floods during 2016 and 2017, which could have strongly influenced our results. The material collection took place in different environmental conditions (for example, under closed or low-density canopy, near forest trails or at the forest edge) but exclusively in temperate forest habitats. In each collection site, we aimed to harvest as many species as possible. We collected a minimum of six specimens, from microhabitats as different as possible as recommended by Cornelissen and others (2003). We identified the species in the field, and all identifications were verified in the laboratory. To exclude the influence of disturbance regime on plant functional traits, we decided to collect plant material only in managed forests with no information about previous disturbances or thinning (Dyderski and others 2016). The random design of the study may be both an advantage (independence of collection sites) and a drawback. Specimens were collected on different dates, phenological stages, climate and collection site conditions, which does not allow assessment of the impact of these factors on the traits studied. However, databases of functional traits (for example, LEDA or Bien) have also been compiled from all available observations, so that intraspecific variability in the impact of these factors on traits is probably unevenly characterized among species. For that reason, our study design resembled the process of development of trait databases.

Each plant was cut, divided into components (leaves, stem, and reproductive organs) and then dried in an oven with forced air circulation at $65^{\circ} \mathrm{C}$ (ULE 600 and UF450, Memmert GmbH + Co. KG, Germany), to a constant mass. Then, leaves were scanned using WinFOLIA 2013 PRO software (Regent Instruments Inc., Quebec, Canada) to measure their area. We measured only a representative subset of mature leaves. Seedlings were excluded from our study. All components were weighed using BP 210 S (Sartorius, Göttingen, Germany) 
and Mettler Toledo PG 1003-S scales, with an accuracy of $0.001 \mathrm{~g}$. We calculated total aboveground biomass (sum of masses of the components; g), specific leaf area (SLA, leaf area/leaf dry biomass; $\mathrm{cm}^{2} \mathrm{~g}^{-1}$ ), total leaf area (SLA $\times$ total leaf biomass per plant; $\mathrm{cm}^{2}$ ) and leaf mass fraction (leaf dry biomass/total aboveground biomass; dimensionless).

\section{Data Analysis}

To assess the impact of species identity, habitat and collection site on SLA, total aboveground biomass, total leaf area and leaf mass fraction, we performed linear mixed models implemented in the lme4::lmer() function (Bates and others 2015). In each model we used collection site as a random effect, and then we performed four models for each trait studied, changing the fixed effects. As fixed effects we used species identity, habitat (coniferous fresh, coniferous wet, deciduous fresh, deciduous wet) and the interaction between species and habitat. Coniferous habitats refer to less-fertile collection sites, while deciduous-to more fertile, fresh-to sites with low and moderate moisture, and wet-to sites with high moisture and wetlands (Table S2). We also performed a null model (intercept only), to assess how adding the independent variables to the model will increase model quality, expressed by Akaike's information criterion (AIC). To assess the impact of fixed effects, we used Tukey's post hoc test using Bonferroni's correction for multiple comparisons. To evaluate the impact of fixed and random effects we calculated marginal $\left(R_{\mathrm{m}}^{2}\right)$ and conditional $\left(R_{\mathrm{C}}^{2}\right)$ coefficients of determination using the MuMIn::r.squaredGLMM() function (Nakagawa and Schielzeth 2013; Bartoń 2018). $R_{\mathrm{m}}^{2}$ refers to the variability explained by fixed effects, and $R_{\mathrm{C}}^{2}$-both by fixed and random effects. Thus, this approach allowed us to exclude and quantify site-specific effects. To compare data obtained in our study with data from the LEDA database, we used the approach of Cordlandwehr and others (2013)—observed versus database SLA plot with a 1:1 line. To assess the differences between mean values provided by the LEDA database (Kleyer and others 2008), we used Student's t-tests using the stats::t.test() function. To decrease the likelihood of incorrectly rejecting a null hypothesis, we applied Bonferroni's corrections to $\mathrm{p}$ values, i.e., we assumed statistically significant differences when $p=0.00032$, that is, $0.05 /$ number of species compared (156). We decided to use the LEDA database as it is the only open database that covers traits of species studied by us in a geographically similar area. All mean values are followed by standard error (SE). All analyses were conducted in R software (R Core Team 2018).

\section{RESUltS}

Variability of SLA, Total Leaf Area, Aboveground Biomass and Leaf Mass Fraction

Specific leaf area of the species studied ranged from $73.96 \mathrm{~cm}^{2} \mathrm{~g}^{-1} \pm \mathrm{SE} 1.36$ (Eriophorum angustifolium), $85.51 \mathrm{~cm}^{2} \mathrm{~g}^{-1} \pm \mathrm{SE} 0.25$ (Vaccinium vitisidaea) and $98.53 \mathrm{~cm}^{2} \mathrm{~g}^{-1} \pm$ SE 2.53 (Galanthus nivalis), to $981.66 \mathrm{~cm}^{2} \mathrm{~g}^{-1} \pm \mathrm{SE} 19.55$ (Impatiens noli-tangere), $981.18 \mathrm{~cm}^{2} \mathrm{~g}^{-1} \pm \mathrm{SE} 21.35$ (Galium palustre) and $863.27 \mathrm{~cm}^{2} \mathrm{~g}^{-1} \pm \mathrm{SE} 2.08$ (Impatiens parviflora; Figure 2). Mean SLA for all species studied was $304.53 \mathrm{~cm}^{2} \mathrm{~g}^{-1} \pm$ SE 12.02 (Table S3). Leaf mass fraction of the total aboveground biomass of the species studied ranged from 1.0 $\pm \mathrm{SE}$ 0.00 (for species such as Hydrocotyle vulgaris, Carex intermedia, Eriophorum angustifolium) to $0.12 \pm \mathrm{SE}$ 0.01 (Agrostis capillaris and Centaurium erythraea) and $0.18 \pm$ SE 0.02 (Anthoxanthum odoratum). Mean leaf mass fraction for all species studied was $0.54 \pm$ SE 0.02 (Table S4). Total leaf area of the species studied ranged from $732.12 \mathrm{~cm}^{2} \pm \mathrm{SE}$ 22.33 (Salvia glutinosa), $597.23 \mathrm{~cm}^{2} \pm \mathrm{SE} 12.01$ (Pteridium aquilinum) and $538.83 \mathrm{~cm}^{2} \pm \mathrm{SE} 17.76$ (Rudbeckia laciniata) to $5.23 \mathrm{~cm}^{2} \pm \mathrm{SE} \quad 0.05$ (Deschampsia flexuosa), $5.82 \mathrm{~cm}^{2} \pm$ SE 0.16 (Stellaria graminea) and $6.09 \mathrm{~cm}^{2} \pm \mathrm{SE} \quad 0.15 \quad$ (Oxycoccus palustris). Mean total leaf area for all species studied was $69.73 \mathrm{~cm}^{2} \pm$ SE 7.51 (Table S5). Total aboveground biomass of the species studied ranged from $7.86 \mathrm{~g} \pm \mathrm{SE} 0.35$ (Rudbeckia laciniata), $5.99 \mathrm{~g} \pm \mathrm{SE}$ 0.19 (Salvia glutinosa) and $4.11 \mathrm{~g} \pm$ SE 0.11 (Cirsium oleraceum) to $0.03 \mathrm{~g} \pm$ SE 0.00 (Galium palustre and Oxalis acetosella) and $0.04 \mathrm{~g} \pm$ SE 0.00 (Hydrocotyle vulgaris; Figure 3). Mean aboveground biomass for all species studied was $0.58 \mathrm{~g} \pm$ SE 0.07 (Table S6).

\section{Comparing SLA Field Measurements and Values from LEDA Database}

For 85 of the 156 species studied, the differences of mean species SLA were greater than $20 \%$ compared to the LEDA database (Kleyer and others 2008), and for 23 species-greater than $50 \%$ (Figure 4, Table S7). We found statistically significant differences $(p<0.00032)$ between mean SLA from the LEDA database and our study for 89 of 156 species studied. Among these 89 species, in case of 


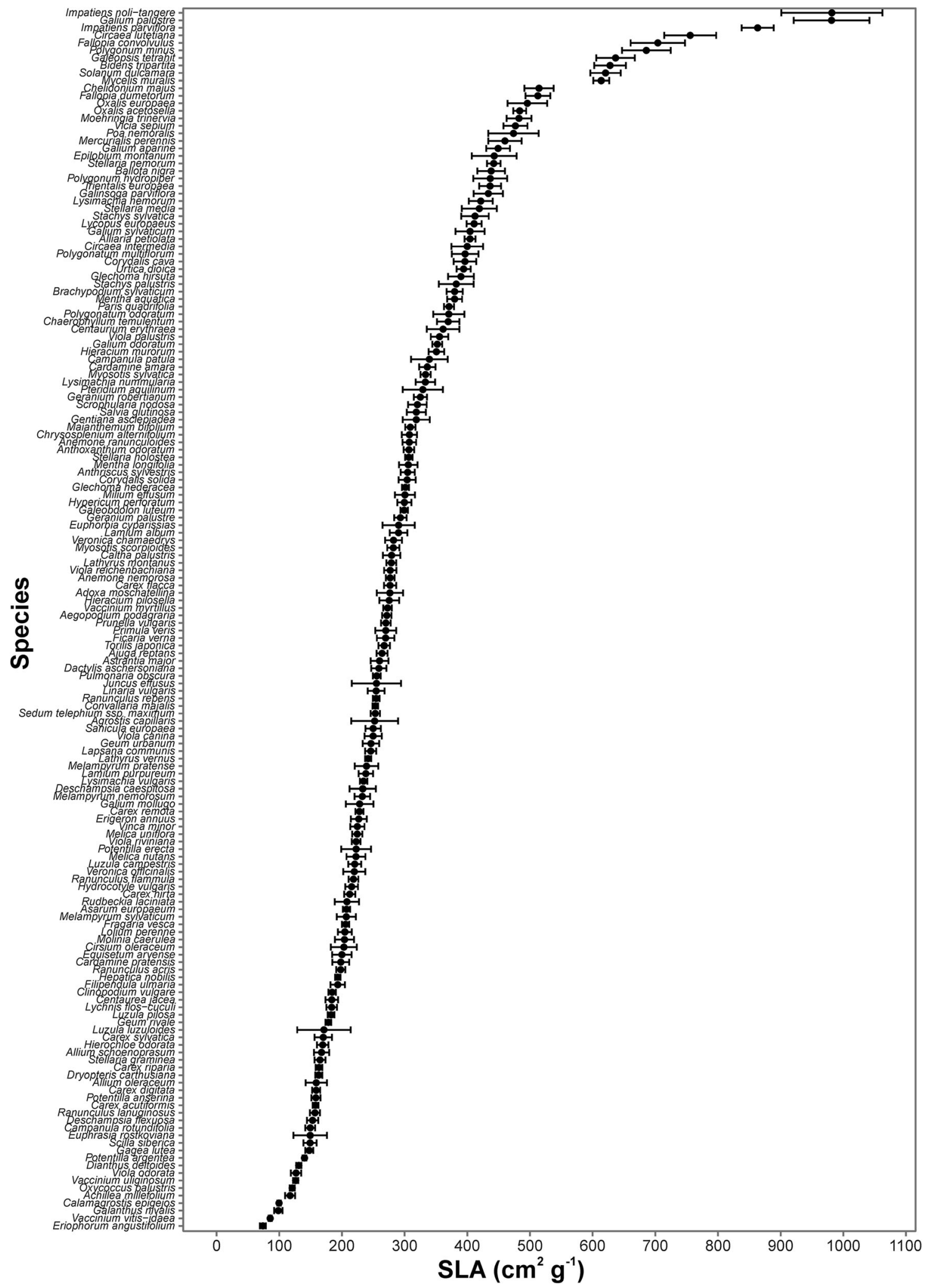

Figure 2. Mean \pm SE SLA of species studied, in an ascending order. 


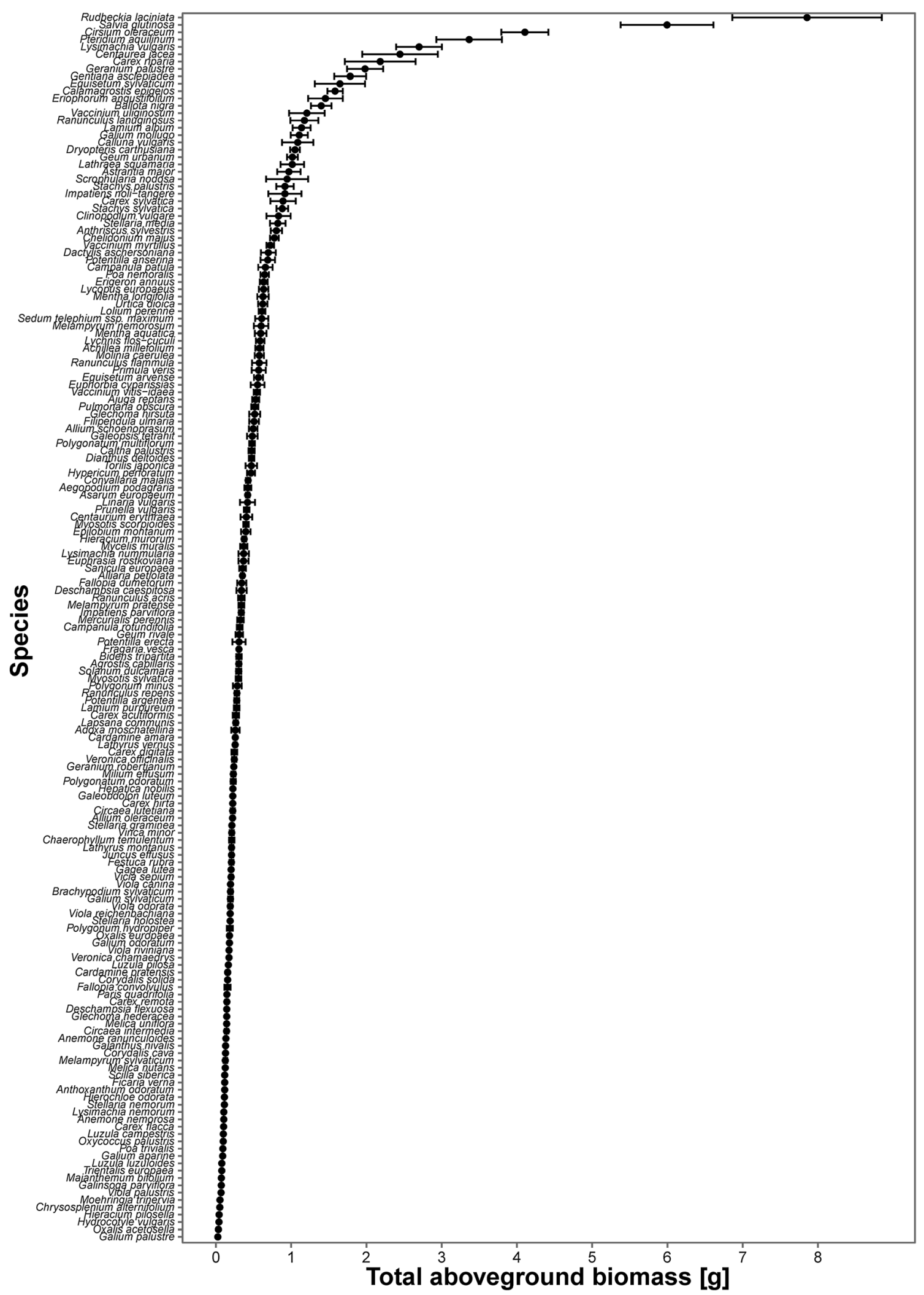

Figure 3. Mean $\pm S E$ aboveground biomass of species studied, in an ascending order. 


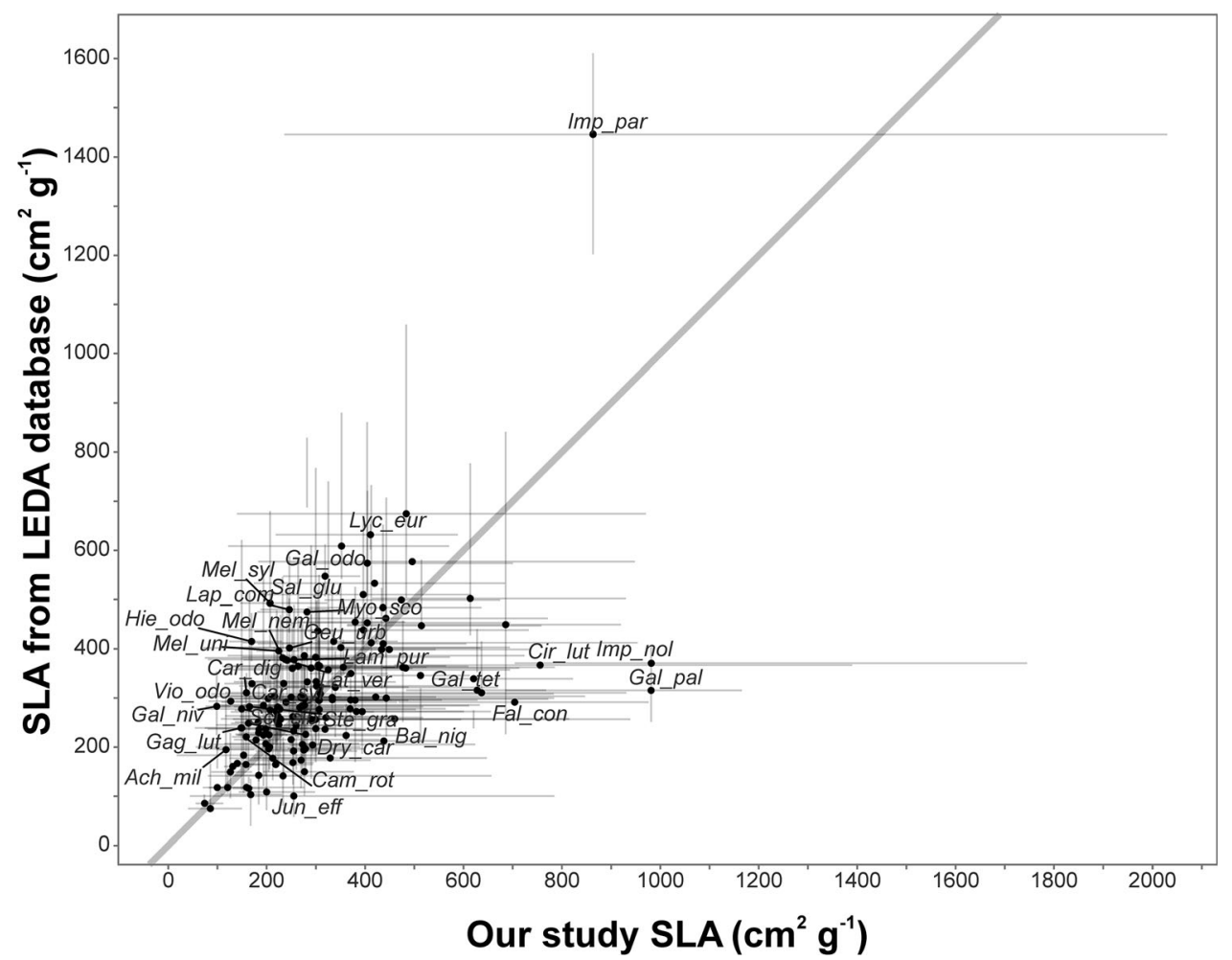

Figure 4. Comparison of SLA obtained in our study with SLA from the LEDA database. The diagonal (1:1) line shows where values are the same. The labels present shortened species names, created by joining the first three letters of genus and species names, for example, Imp_par_Impatiens parviflora. To increase the figure's readability only species with a difference in SLA greater than $50 \%$ between the two sources compared were labeled. Vertical and horizontal lines show the range (minimum and maximum) of SLA values obtained from the two sources.

22 species relative differences between mean SLA from the LEDA database and our study were lower than $20 \%$ (Table S7). The minimum SLA was lower for 79, and the maximum SLA was higher for 60, of the 108 species from LEDA for which SLA ranges were provided. For 78 species, the differences of minimum species SLA were greater than $20 \%$, and for 38 species-greater than $50 \%$. For 68 of 109 species studied, the differences of maximum species SLA were greater than $20 \%$ compared to the LEDA database (Kleyer and others 2008), and for 29 species-greater than $50 \%$. For 96 of the species studied, we collected more samples (from 1 up to 221 specimens) for SLA analysis than in the LEDA database.

\section{Variability of Studied Traits Explained by Species Identity and Collection Site}

For all traits studied, the best fit models were those including the interaction between species and habitat (Table 1). For the SLA model, $58 \%$ of the variability was explained by all the fixed effects together and $82 \%$ by both fixed and random effects
(Tables S8-S11). For the leaf mass fraction model, $54 \%$ of the variability was explained by fixed effects, and $89 \%$ by both fixed and random effects (Tables S12-S15). For the total leaf area model, $36 \%$ of the variability was explained by fixed effects and $74 \%$ by both fixed and random effects (Tables S16-19). For total aboveground biomass, the best model explained $37 \%$ of variability by fixed effects, and $75 \%$ by both fixed and random effects (Tables S20-S23). However, in all traits studied the level of variability explained by fixed effects between the best models and models including only species identity ranged from only 0.045 (leaf mass fraction) to 0.100 (biomass) (Figure 5). Moreover, for all the traits studied, the models including the interaction of species and habitat explained the highest amount of variability.

\section{Discussion}

\section{What are the Sources of Variability?}

In our study, we found higher inter- than intraspecific variability of the traits analyzed. Variability of the traits studied may result from 
Table 1. Comparison of Linear Mixed Models for the Parameters Studied

\begin{tabular}{|c|c|c|c|c|}
\hline Response & Fixed effects & AIC & $R_{\mathrm{m}}^{2}$ & $R_{\mathrm{C}}^{2}$ \\
\hline \multirow[t]{4}{*}{ SLA } & Intercept only & $61,395.630$ & 0.000 & 0.530 \\
\hline & Species & $57,457.420$ & 0.526 & 0.755 \\
\hline & Habitat & $61,360.600$ & 0.027 & 0.530 \\
\hline & Species $\times$ habitat & $56,054.150$ & 0.577 & 0.817 \\
\hline \multirow[t]{4}{*}{ LMF } & Intercept only & -1679.004 & 0.000 & 0.498 \\
\hline & Species & -5438.193 & 0.499 & 0.843 \\
\hline & Habitat & -1675.422 & 0.027 & 0.496 \\
\hline & Species $\times$ habitat & -6299.425 & 0.544 & 0.893 \\
\hline \multirow[t]{4}{*}{ TLA } & Intercept only & $52,286.910$ & 0.000 & 0.528 \\
\hline & Species & $50,374.540$ & 0.261 & 0.646 \\
\hline & Habitat & $52,267.520$ & 0.009 & 0.532 \\
\hline & Species $\times$ habitat & $49,219.380$ & 0.359 & 0.740 \\
\hline \multirow[t]{4}{*}{ Aboveground biomass } & Intercept only & 5102.774 & 0.000 & 0.548 \\
\hline & Species & 3600.211 & 0.271 & 0.756 \\
\hline & Habitat & 5102.840 & 0.024 & 0.547 \\
\hline & Species $\times$ habitat & 3023.296 & 0.371 & 0.751 \\
\hline
\end{tabular}

Intercept only is a null model; in all models collection site was a random effect.

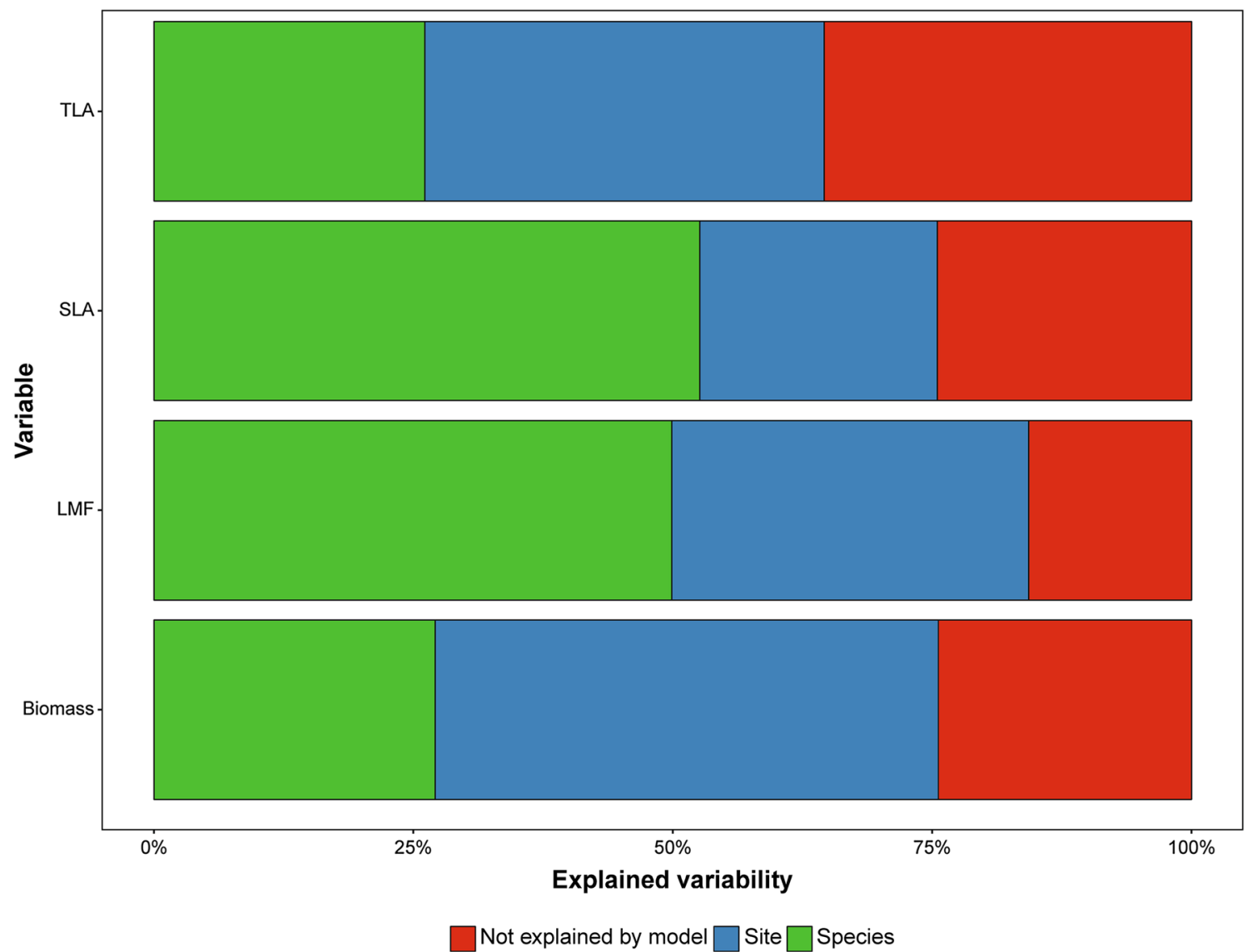

Figure 5. The level of trait variability explained by species and collection site. 
different factors. As there are numerous possible sources of variability in trait values, we aimed to group the main varying factors into three groups: environmental, biological and geographical factors.

Environmental sources of variability in trait values are mainly connected with the characteristics of the collection sites. The features of the collection site may be expressed through stand or species density, stand age, dominant tree species in a stand or position in the forest (that is, core or edge). However, they are mainly connected with one primary factor which is the availability of light (Knight and others 2008; Niinemets 2010; Paź and others 2018). Moreover, light availability can strongly modify SLA, total leaf area and specimen biomass (Jagodziński and others 2016). However, studies of functional traits of seedlings of seven tree species revealed that the species identity caused much more variability than light availability (Dyderski and Jagodziński 2019). Wide ranges of trait values may result also from collection site differences, differentiated habitats where the plants grow, the phase of the growing season (for example, early, middle, or late) and from year-to-year variation in growing season, and so on (Tremblay and Larocque 2001; Zheng and others 2015; Harayama and others 2016; Libalah and others 2017; Meng and others 2017).

As one of the most significant biological factors, life strategy influences the variability of parameters studied through functional traits such as height, leaf area, leaf mass per area, leaf nitrogen content per unit mass, seed mass and stem specific density (Díaz and others 2016). For example, at the beginning of the growth season the mean SLA of some species shows an increasing trend (Jagodziński and others 2016). On the other hand, with the aging of leaves more carbon-rich compounds occur in their tissues, which makes the tissue thicker and leads to reduction in SLA (Reich and others 1991). Moreover, plants of shaded habitats tend to produce leaves of high SLA, as in their case the growth limiting factor is lack of light (Planchais and Sinoquet 1998; Milla and others 2008; Wyka and others 2012).

The geographical factors, which determine leaf size at the global scale, are amplitudes of leaf and air temperatures during day and night (Wright and others 2017). As total leaf area strongly depends on the geographical latitude, it shows the lowest values for plants growing near the Arctic and Antarctic Circles, and the highest values for equatorial plants (Wright and others 2017). Because the collection of plant specimens in this study took place in the climate transition between maritime and conti- nental, we assumed that the results of leaf size obtained in our study would be determined mainly by the geographical factor. An additional confirmation of that hypothesis was the latitudinal pattern presented by leaves of small area (for example, Vaccinium vitis-idaea, Vaccinium uliginosum) on habitats typical of the boreal climate zone, and leaves of large area (for example, Salvia glutinosa, Scrophularia nodosa) on habitats typical of the temperate zone.

As the impact of each group of factors described is strongly connected with one another, the following observations can be made. Plants of high SLA and low biomass values were mainly connected with deciduous forests of high moisture, as less light availability and higher nitrogen availability allows for thinner leaf blades. On the other hand, the biomass was generally higher in coniferous forests of high moisture, as they relate to high light availability. This may be justified generally by the appearance of the Ericaceae family of high biomass and low SLA values in those habitats. Therefore, as some species occurred on strictly determined habitats (for example, only in coniferous or only in deciduous forests), this had a significant influence on our results. Therefore, the fact that the models including the interaction of species and habitat explained the highest amount of variability may be justified by the ecological preferences of the species studied.

\section{Differences Between SLA Field Measurements and LEDA Database}

We found that $57 \%$ out of the species studied had significant differences compared to the LEDA database. Moreover, $15 \%$ of the species studied differed by more than $50 \%$ from the values contained in the LEDA database. This could result from the limited study area (region-scale), as the collection sites were not evenly distributed across the wide ranges of species' occurrences. However, our sampling effort included relatively high habitat diversity-for $62 \%$ out of the species studied we collected a higher number of specimens than are included in the LEDA database. Our findings highlight that thorough consideration of database composition must be taken during their use, as the values presented are significantly influenced by the methodology of sampling. 


\section{Intra- and Interspecific Variability of Trait Values Differ Among Spatial Scales}

We found that SLA and LMF were driven mainly by species identity and that TLA and total aboveground biomass were mainly site-specific. Numerous researchers have shown that the values of traits of different plant species are site-specific and differ among gradients or between different functional groups, producing a functional continuum instead of a clear-cut classification of species (Albert and others 2010a; Jung and others 2010; Mayfield and others 2013; Popović and others 2016; Helsen and others 2018). Significant complex plastic responses of different plant species must be also taken into consideration while analyzing ecological processes at a community level (Kichenin and others 2013). Intraspecific trait variation sources are now the subject of statistical modeling, and assessing the level of intraspecific variability of species might be crucial in some studies (Moran and others 2016). Nevertheless, it is the scale of study that determines the appropriate type of trait data that should be used. For that reason, this decision must always be taken when adapting the methodology to the aim of the survey (Albert and others 2010b). A solution containing a trade-off between sampling effort and conducting research on a wide study area might be the application of recently developed tools integrating trait variability at both intra- and interspecific levels (Violle and others 2012), although some cases require solutions. For example, in the case of testing a physiological hypothesis, it is obvious that direct trait measurements are required, as the intraspecific trait variability may be crucial to properly quantify the correlations studied. Moreover, a thorough understanding of intraspecific trait variability can also contribute to the explanation of ecological processes at the community to global levels (Jung and others 2010; Moran and others 2016; Siefert and others 2015). On the other hand, running ecological surveys of wide spatial scale at the community or greater levels justifies the use of mean trait values from databases, as we showed that the impact of collection site and habitat is much lower than the significance of species identity. It is also worth noting that intraspecific trait variability tends to be lower when comparing organ-level (and not whole-plant) traits, such as leaf-connected traits in this study (Siefert and others 2015), which implies that direct measurements might be dispensable in wide-scale studies. However, all functional traits can differ across a large latitudinal gradient (De Frenne and others 2011, 2013; Lemke and others 2015). Therefore, using a single trait value and omitting the importance of intraspecific variability can obscure a significant part of the full characteristics of a given species (Albert and others 2010b).

\section{Ecological Implications}

Our study revealed higher interspecific than intraspecific variability of the traits studied. This result justifies the use of mean values of SLA, total leaf area, aboveground biomass and leaf mass fraction from databases in studies at the habitat scale and wider spatial units. The analysis of functional traits and functional variability based on calculated mean SLA values can serve for further verification of SLA worthiness as a proxy of correlated traits, such as total leaf area, nitrogen content, seed mass or plant height (Díaz and others 2016). Wide application of SLA as a feature coupled with other parameters by numerous studies (Dyderski and others 2016; Kattenborn and others 2017; Czortek and others 2018) determines the need for thorough recognition and understanding of its variability. We also found that the LEDA database (Kleyer and others 2008), as a commonly used source of mean SLA values, often presents values obtained using only a few specimens. In the context of the given shortcomings, this is a significant limitation. Nevertheless, our study showed that mean trait values depend on site-specific factors to only a small degree.

Our results have increased knowledge of the variability of the functional traits analyzed, which is an important concern for improving the fits of primary net production or carbon sequestration models to the specifics of forest ecosystems (Pompa-García and others 2017; Wright and others 2017; Jagodziński and others 2018). Functional traits are also used in nature conservation to assess the level of human impact on the environment, caused, for example, by land-use change, biological invasions or forest management (te Beest and others 2015; Dyderski and others 2016; Czortek and others 2018). Use of trait values from databases not acknowledging intraspecific variability is biased by the uncertainty about this variability. For that reason, our results reduced uncertainty of analysis using mean trait values conducted in order to assess human impacts on ecosystems. Thus, our study might support the assumption that level of intraspecific variability of functional traits is lower than interspecific variability. 


\section{ACKNOWLEDGEMENTS}

The study was partially financed by the Institute of Dendrology, Polish Academy of Sciences, Kórnik, Poland. We are grateful to Dr. Lee E. Frelich (Department of Forest Resources, University of Minnesota, USA) for linguistic revision of the manuscript. We are thankful to two anonymous reviewers for valuable and thorough comments on the earlier draft of the manuscript.

\section{OPEN ACCESS}

This article is distributed under the terms of the Creative Commons Attribution 4.0 International License (http://creativecommons.org/licenses/by/4 $.0 /$ ), which permits unrestricted use, distribution, and reproduction in any medium, provided you give appropriate credit to the original author(s) and the source, provide a link to the Creative Commons license, and indicate if changes were made.

\section{REFERENCES}

Albert CH, Grassein F, Schurr FM, Vieilledent G, Violle C. 2011. When and how should intraspecific variability be considered in trait-based plant ecology? Perspectives in Plant Ecology, Evolution and Systematics 13:217-25.

Albert CH, Thuiller W, Yoccoz NG, Douzet R, Aubert S, Lavorel S. 2010a. A multi-trait approach reveals the structure and the relative importance of intra- vs. interspecific variability in plant traits. Functional Ecology 24:1192-201.

Albert CH, Thuiller W, Yoccoz NG, Soudant A, Boucher F, Saccone P, Lavorel S. 2010b. Intraspecific functional variability: extent, structure and sources of variation. Journal of Ecology 98:604-13.

Bartoń K. 2018. MuMIn: Multi-modal inference. Model selection and model averaging based on information criteria (AICc and alike). https://cran.r-project.org/web/packages/MuMIn/i ndex.html. Accessed 24 July 2019.

Bates D, Mächler M, Bolker B, Walker S. 2015. Fitting linear mixed-effects models using lme4. Journal of Statistical Software $67: 1-48$.

Bjorkman AD, Myers-Smith IH, Elmendorf SC, Normand S, Rüger N, Beck PSA, Blach-Overgaard A, Blok D, Cornelissen JHC, Forbes BC, Georges D, Goetz SJ, Guay KC, Henry GHR, HilleRisLambers J, Hollister RD, Karger DN, Kattge J, Manning P, Prevéy JS, Rixen C, Schaepman-Strub G, Thomas HJD, Vellend $M$, Wilmking $M$, Wipf S, Carbognani M, Hermanutz L, Lévesque E, Molau U, Petraglia A, Soudzilovskaia NA, Spasojevic MJ, Tomaselli M, Vowles T, Alatalo JM, Alexander HD, Anadon-Rosell A, Angers-Blondin S, te Beest M, Berner L, Björk RG, Buchwal A, Buras A, Christie K, Cooper EJ, Dullinger S, Elberling B, Eskelinen A, Frei ER, Grau O, Grogan $P$, Hallinger $M$, Harper KA, Heijmans MMPD, Hudson J, Hülber $\mathrm{K}$, Iturrate-Garcia M, Iversen CM, Jaroszynska F, Johnstone JF, Jørgensen RH, Kaarlejärvi E, Klady R, Kuleza S, Kulonen A, Lamarque LJ, Lantz T, Little CJ, Speed JDM, Michelsen A, Milbau A, Nabe-Nielsen J, Nielsen SS, Ninot JM, Oberbauer SF, Olofsson J, Onipchenko VG, Rumpf SB, Semenchuk P, Shetti R, Collier LS, Street LE, Suding KN, Tape
KD, Trant A, Treier UA, Tremblay J-P, Tremblay M, Venn S, Weijers S, Zamin T, Boulanger-Lapointe N, Gould WA, Hik DS, Hofgaard A, Jónsdóttir IS, Jorgenson J and others. 2018. Plant functional trait change across a warming tundra biome. Nature 562:57-62.

Blonder B, Enquist BJ, Graae BJ, Kattge J, Maitner BS, MoruetaHolme N, Ordonez A, Šímová I, Singarayer J, Svenning J-C, Valdes PJ, Violle C. 2018. Late quaternary climate legacies in contemporary plant functional composition. Global Change Biology 24:4827-40.

Canessa R, Saldaña A, Ríos RS, Gianoli E. 2018. Functional trait variation predicts distribution of alien plant species across the light gradient in a temperate rainforest. Perspectives in Plant Ecology, Evolution and Systematics 32:49-55.

Carlos NA, Rossatto DR. 2017. Leaf traits combinations may explain the occurrence of savanna herbaceous species along a gradient of tree encroachment. Theoretical and Experimental Plant Physiology 29:155-63.

Castro-Díez P, Langendoen T, Poorter L, Saldana-Lopez A. 2011. Predicting Acacia invasive success in South Africa on the basis of functional traits, native climatic niche and human use. Biodiversity and Conservation 20:2729-43.

Chapin FSIII, Zavaleta ES, Eviner VT, Naylor RL, Vitousek PM, Reynolds HL, Hooper DU, Lavorel S, Sala OE, Hobbie SE, Mack MC, Díaz S. 2000. Consequences of changing biodiversity. Nature 405:234-42.

Cordlandwehr V, Meredith RL, Ozinga WA, Bekker RM, van Groenendael JM, Bakker JP. 2013. Do plant traits retrieved from a database accurately predict on-site measurements? Journal of Ecology 101:662-70.

Cornelissen JHC, Lavorel S, Garnier E, Díaz S, Buchmann N, Gurvich DE, Reich PB, ter Steege H, Morgan HD, van der Heijden MGA, Pausas JG, Poorter H. 2003. A handbook of protocols for standardised and easy measurement of plant functional traits worldwide. Australian Journal of Botany $51: 335$.

Cornwell WK, Cornelissen JHC, Amatangelo K, Dorrepaal E, Eviner VT, Godoy O, Hobbie SE, Hoorens B, Kurokawa H, Pérez-Harguindeguy N, Quested HM, Santiago LS, Wardle DA, Wright IJ, Aerts R, Allison SD, Bodegom PV, Brovkin V, Chatain A, Callaghan TV, Díaz S, Garnier E, Gurvich DE, Kazakou E, Klein JA, Read J, Reich PB, Soudzilovskaia NA, Vaieretti MV, Westoby M. 2008. Plant species traits are the predominant control on litter decomposition rates within biomes worldwide. Ecology Letters 11:1065-71.

Czortek P, Delimat A, Dyderski MK, Zięba A, Jagodziński AM, Jaroszewicz B. 2018. Climate change, tourism and historical grazing influence the distribution of Carex lachenalii Schkuh$\mathrm{r}-\mathrm{A}$ rare arctic-alpine species in the Tatra Mts. Science of The Total Environment 618:1628-37.

De Frenne P, Brunet J, Shevtsova A, Kolb A, Graae BJ, Chabrerie O, Cousins SA, Decocq G, De Schrijver A, Diekmann M, Gruwez R, Heinken T, Hermy M, Nilsson C, Stanton S, Tack W, Willaert J, Verheyen K. 2011. Temperature effects on forest herbs assessed by warming and transplant experiments along a latitudinal gradient. Global Change Biology 17:324053.

De Frenne P, Graae BJ, Rodríguez-Sánchez F, Kolb A, Chabrerie O, Decocq G, De Kort H, De Schrijver A, Diekmann M, Eriksson O, Gruwez R, Hermy M, Lenoir J, Plue J, Coomes DA, Verheyen K. 2013. Latitudinal gradients as natural laboratories to infer species' responses to temperature. Journal of Ecology 101:784-95. 
Díaz S, Kattge J, Cornelissen JHC, Wright IJ, Lavorel S, Dray S, Reu B, Kleyer M, Wirth C, Colin Prentice I, Garnier E, Bönisch G, Westoby M, Poorter H, Reich PB, Moles AT, Dickie J, Gillison AN, Zanne AE, Chave J, Joseph Wright S, Sheremet'ev SN, Jactel H, Baraloto C, Cerabolini B, Pierce S, Shipley B, Kirkup D, Casanoves F, Joswig JS, Günther A, Falczuk V, Rüger N, Mahecha MD, Gorné LD. 2016. The global spectrum of plant form and function. Nature 529:167-71.

Díaz S, Cabido M. 2001. Vive la différence: plant functional diversity matters to ecosystem processes. Trends in Ecology $\delta$ Evolution 16:646-55.

Dyderski MK, Czapiewska N, Zajdler M, Tyborski J, Jagodziński AM. 2016. Functional diversity, succession, and human-mediated disturbances in raised bog vegetation. Science of The Total Environment 562:648-57.

Dyderski MK, Jagodziński AM. 2019. Functional traits of acquisitive invasive woody species differ from conservative invasive and native species. NeoBiota 41:91-113.

Enquist BJ, Condit R, Peet RK, Schildhauer M, Thiers BM. 2016. Cyberinfrastructure for an integrated botanical information network to investigate the ecological impacts of global climate change on plant biodiversity. PeerJ Preprints 4:e2615v2.

Enquist BJ, Niklas KJ. 2002. Global allocation rules for patterns of biomass partitioning in seed plants. Science 295:1517-20.

Freschet GT, Dias ATC, Ackerly DD, Aerts R, van Bodegom PM, Cornwell WK, Dong M, Kurokawa H, Liu G, Onipchenko VG, Ordoñez JC, Peltzer DA, Richardson SJ, Shidakov II, Soudzilovskaia NA, Tao J, Cornelissen JHC. 2011. Global to community scale differences in the prevalence of convergent over divergent leaf trait distributions in plant assemblages. Global Ecology and Biogeography 20:755-65.

Gilliam FS. 2007. The ecological significance of the herbaceous layer in temperate forest ecosystems. Bioscience 57:845-58.

GUS. 2017. Rocznik Statystyczny Rzeczypospolitej Polskiej 2017. Warsaw: Główny Urząd Statystyczny.

Harayama H, Ishida A, Yoshimura J. 2016. Overwintering evergreen oaks reverse typical relationships between leaf traits in a species spectrum. Royal Society Open Science 3:160276.

Helsen K, Kapás RE, Rakvaag G, Speed JDM, Graae BJ. 2018. Impacts of an invasive plant on primary production: Testing a functional trait-based framework with a greenhouse experiment. Botta-Dukát Z, editor. Journal of Vegetation Science 29:157-66.

Hernández-Calderón E, Méndez-Alonzo R, Martínez-Cruz J, González-Rodríguez A, Oyama K. 2014. Altitudinal changes in tree leaf and stem functional diversity in a semi-tropical mountain. Roxburgh S, editor. Journal of Vegetation Science 25:955-66.

Hunt R, Cornelissen JHC. 1997. Components of relative growth rate and their interrelations in 59 temperate plant species. New Phytologist 135:395-417.

Ivanova LA, Zolotareva NV, Ronzhina DA, Podgaevskaya EN, Migalina SV, Ivanov LA. 2018. Leaf functional traits of abundant species predict productivity in three temperate herbaceous communities along an environmental gradient. Flora 239:1 1-19.

Jagodziński AM, Dyderski MK, Gęsikiewicz K, Horodecki P, Cysewska A, Wierczyńska S, Maciejczyk K. 2018. How do tree stand parameters affect young Scots pine biomass? Allometric equations and biomass conversion and expansion factors. Forest Ecology and Management 409:74-83.
Jagodziński AM, Dyderski MK, Rawlik K, Kạtna B. 2016. Seasonal variability of biomass, total leaf area and specific leaf area of forest understory herbs reflects their life strategies. Forest Ecology and Management 374:71-81.

Jung V, Violle C, Mondy C, Hoffmann L, Muller S. 2010. Intraspecific variability and trait-based community assembly: Intraspecific variability and community assembly. Journal of Ecology 98:1134-40.

Kattenborn T, Fassnacht FE, Pierce S, Lopatin J, Grime JP, Schmidtlein S. 2017. Linking plant strategies and plant traits derived by radiative transfer modelling. Journal of Vegetation Science 28:717-27.

Ketterings QM, Coe R, van Noordwijk M, Ambagau Y, Palm CA. 2001. Reducing uncertainty in the use of allometric biomass equations for predicting above-ground tree biomass in mixed secondary forests. Forest Ecology and Management 146:199_ 209.

Kichenin E, Wardle DA, Peltzer DA, Morse CW, Freschet GT. 2013. Contrasting effects of plant inter- and intraspecific variation on community-level trait measures along an environmental gradient. Functional Ecology 27:1254-61.

Kleyer M, Bekker RM, Knevel IC, Bakker JP, Thompson K, Sonnenschein M, Poschlod P, van Groenendael JM, Klimeš L, Klimešová $J$, Klotz $S$, Rusch GM, Hermy $M$, Adriaens D, Boedeltje G, Bossuyt B, Dannemann A, Endels P, Götzenberger L, Hodgson JG, Jackel A-K, Kühn I, Kunzmann D, Ozinga WA, Römermann C, Stadler M, Schlegelmilch J, Steendam HJ, Tackenberg O, Wilmann B, Cornelissen JHC, Eriksson O, Garnier E, Peco B. 2008. The LEDA Traitbase: a database of life-history traits of the Northwest European flora. Journal of Ecology 96:1266-74.

Kleyer M, Trinogga J, Cebrián-Piqueras MA, Trenkamp A, Fløjgaard C, Ejrnæs R, Bouma TJ, Minden V, Maier M, Mantilla-Contreras J, Albach DC, Blasius B. 2019. Trait correlation network analysis identifies biomass allocation traits and stem specific length as hub traits in herbaceous perennial plants. Journal of Ecology . https://doi.org/10.1111/1365-27 45.13066.

Knight KS, Oleksyn J, Jagodzinski AM, Reich PB, Kasprowicz M. 2008. Overstorey tree species regulate colonization by native and exotic plants: a source of positive relationships between understorey diversity and invasibility. Diversity and Distributions 14:666-75.

Kwon B, Kim H, Jeon J, Yi M. 2016. Effects of temporal and interspecific variation of specific leaf area on leaf area index estimation of temperate broadleaved forests in Korea. Forests 7:215.

Lemke IH, Kolb A, Graae BJ, De Frenne P, Acharya KP, Blandino C, Brunet J, Chabrerie O, Cousins SAO, Decocq G, Heinken T, Hermy M, Liira J, Schmucki R, Shevtsova A, Verheyen K, Diekmann M. 2015. Patterns of phenotypic trait variation in two temperate forest herbs along a broad climatic gradient. Plant Ecology 216:1523-36.

Libalah MB, Droissart V, Sonké B, Hardy OJ, Drouet T, Pescador DS, Kenfack D, Thomas DW, Chuyong GB, Couteron P. 2017. Shift in functional traits along soil fertility gradient reflects non-random community assembly in a tropical African rainforest. Plant Ecology and Evolution 150:265-78.

Ma W, Shi P, Li W, He Y, Zhang X, Shen Z, Chai S. 2010. Changes in individual plant traits and biomass allocation in alpine meadow with elevation variation on the Qinghai-Tibetan Plateau. Science China Life Sciences 53:1142-51. 
Maréchaux I, Bonal D, Bartlett MK, Burban B, Coste S, Courtois EA, Dulormne M, Goret J-Y, Mira E, Mirabel A, Sack L, Stahl C, Chave J. 2018. Dry-season decline in tree sapflux is correlated with leaf turgor loss point in a tropical rainforest. Functional Ecology 32:2285-97.

Mayfield MM, Dwyer JM, Chalmandrier L, Wells JA, Bonser SP, Catterall CP, DeClerck F, Ding Y, Fraterrigo JM, Metcalfe DJ, Queiroz C, Vesk PA, Morgan JW. 2013. Differences in forest plant functional trait distributions across land-use and productivity gradients. American Journal of Botany 100:1356-68.

McCoy-Sulentic ME, Kolb TE, Merritt DM, Palmquist EC, Ralston BE, Sarr DA. 2017. Variation in species-level plant functional traits over wetland indicator status categories. Ecology and Evolution 7:3732-44.

Meng H, Wei X, Franklin SB, Wu H, Jiang M. 2017. Geographical variation and the role of climate in leaf traits of a relict tree species across its distribution in China. Plant Biology 19:552-61.

Milla R, Reich PB, Niinemets Ü, Castro-Díez P. 2008. Environmental and developmental controls on specific leaf area are little modified by leaf allometry. Functional Ecology 22:56576.

Moran EV, Hartig F, Bell DM. 2016. Intraspecific trait variation across scales: implications for understanding global change responses. Global Change Biology 22:137-50.

Müller C, Cramer W, Hare WL, Lotze-Campen H. 2011. Climate change risks for African agriculture. Proceedings of the National Academy of Sciences of the United States of America 108:4313-15.

Muller RN. 2014. Nutrient relations of the herbaceous layer in deciduous forest ecosystems. In: Gilliam F, Ed. The Herbaceous Layer in Forests of Eastern North America. Oxford: Oxford University Press. p 12-34.

Nakagawa S, Schielzeth H. 2013. A general and simple method for obtaining R2 from generalized linear mixed-effects models. Methods in Ecology and Evolution 4:133-42.

Niinemets Ü. 2010. A review of light interception in plant stands from leaf to canopy in different plant functional types and in species with varying shade tolerance. Ecological Research 25:693-714.

Ordonez A. 2014. Global meta-analysis of trait consistency of non-native plants between their native and introduced areas. Global Ecology and Biogeography 23:264-73.

Paź S, Czapiewska N, Dyderski MK, Jagodziński AM. 2018. Assessment of Carya ovata (Mill.) K.Koch introduction to the potential oak-hornbeam forest habitat in the Czerniejewo Forest District. Sylwan 162:41-8.

Peeters PJ. 2002. Correlations between leaf structural traits and the densities of herbivorous insect guilds. Biological Journal of the Linnean Society 77:43-65.

Peichl M, Arain MA. 2007. Allometry and partitioning of aboveand belowground tree biomass in an age-sequence of white pine forests. Forest Ecology and Management 253:68-80.

Pierce S, Brusa G, Vagge I, Cerabolini BEL. 2013. Allocating CSR plant functional types: the use of leaf economics and size traits to classify woody and herbaceous vascular plants. Functional Ecology 27:1002-10.

Planchais I, Sinoquet H. 1998. Foliage determinants of light interception in sunny and shaded branches of Fagus sylvatica (L.). Agricultural and Forest Meteorology 89:241-53.
Pompa-García M, Angel Sigala-Rodriguez J, Jurado E, Flores J. 2017. Tissue carbon concentration of 175 Mexican forest species. iForest 10:754-8.

Poorter H, De Jong R. 1999. A comparison of specific leaf area, chemical composition and leaf construction costs of field plants from 15 habitats differing in productivity. New Phytologist 143:163-76.

Poorter H, Jagodzinski AM, Ruiz-Peinado R, Kuyah S, Luo Y, Oleksyn J, Usoltsev VA, Buckley TN, Reich PB, Sack L. 2015. How does biomass distribution change with size and differ among species? An analysis for 1200 plant species from five continents. New Phytologist 208:736-49.

Poorter H, Niklas KJ, Reich PB, Oleksyn J, Poot P, Mommer L. 2012. Biomass allocation to leaves, stems and roots: metaanalyses of interspecific variation and environmental control: Tansley review. New Phytologist 193:30-50.

Poorter H, Remkes C. 1990. Leaf area ratio and net assimilation rate of 24 wild species differing in relative growth rate. Oecologia 83:553-9.

Popović Z, Bojović S, Matić R, Stevanović B, Karadžić B. 2016. Comparative ecophysiology of seven spring geophytes from an oak-hornbeam forest. Brazilian Journal of Botany 39:29-40.

R Core Team. 2018. R: a language and environment for statistical computing. Vienna, Austria: R Foundation for Statistical Computing. http://www.R-project.org/. Accessed 24 July 2019

Reich PB, Ellsworth DS, Walters MB. 1998a. Leaf structure (specific leaf area) modulates photosynthesis-nitrogen relations: evidence from within and across species and functional groups. Functional Ecology 12:948-58.

Reich PB, Tjoelker MG, Walters MB, Vanderklein DW, Buschena C. 1998b. Close association of RGR, leaf and root morphology, seed mass and shade tolerance in seedlings of nine boreal tree species grown in high and low light. Functional Ecology $12: 327-38$

Reich PB, Uhl C, Walters M, Ellsworth D. 1991. Leaf life-span as a determinant of leaf structure and function among 23 Amazonian tree species. Oecologia 86:16-24.

Rudner M, Gross M. 2012. Plant functional types for Nardus grasslands in the Black Forest. Tuexenia 32:141-66.

Schmidhuber J, Tubiello FN. 2007. Global food security under climate change. Proceedings of the National Academy of Sciences of the United States of America 104:19703-8.

Schumacher J, Roscher C. 2009. Differential effects of functional traits on aboveground biomass in semi-natural grasslands. Oikos 118:1659-68.

Segura M, Kanninen M. 2005. Allometric models for tree volume and total aboveground biomass in a tropical humid forest in Costa Rica. Biotropica 37:2-8.

Siefert A, Violle C, Chalmandrier L, Albert CH, Taudiere A, Fajardo A, Aarssen LW, Baraloto C, Carlucci MB, Cianciaruso MV, Dantas V, Bello F, Duarte LD, Fonseca CR, Freschet GT, Gaucherand S, Gross N, Hikosaka K, Jackson B, Jung V, Kamiyama C, Katabuchi M, Kembel SW, Kichenin E, Kraft NJ, Lagerström A, Bagousse-Pinguet YL, Li Y, Mason N, Messier J, Nakashizuka T, Overton JM, Peltzer DA, Pérez-Ramos IM, Pillar VD, Prentice HC, Richardson S, Sasaki T, Schamp BS, Schöb C, Shipley B, Sundqvist M, Sykes MT, Vandewalle M, Wardle DA. 2015. A global meta-analysis of the relative extent of intraspecific trait variation in plant communities. Ecology Letters 18:1406-19. 
Smart SM, Glanville HC, del Blanes MC, Mercado LM, Emmett BA, Jones DL, Cosby BJ, Marrs RH, Butler A, Marshall MR, Reinsch S, Herrero-Jáuregui C, Hodgson JG. 2017. Leaf dry matter content is better at predicting above-ground net primary production than specific leaf area. Functional Ecology 31:1336-44.

Stevens CJ, David TI, Storkey J. 2018. Atmospheric nitrogen deposition in terrestrial ecosystems: Its impact on plant communities and consequences across trophic levels. Functional Ecology 32:1757-69.

Taylor HR, Radford IJ, Price C, Grierson P. 2018. Low resource availability limits weed invasion of tropical savannas. Biological Invasions 20:861-75.

te Beest M, Esler KJ, Richardson DM. 2015. Linking functional traits to impacts of invasive plant species: a case study. Plant Ecology 216:293-305.

Tremblay NO, Larocque GR. 2001. Seasonal dynamics of understory vegetation in four eastern Canadian forest types. International Journal of Plant Sciences 162:271-86.

Violle C, Enquist BJ, McGill BJ, Jiang L, Albert CH, Hulshof C, Jung V, Messier J. 2012. The return of the variance: intraspecific variability in community ecology. Trends in Ecology \& Evolution 27:244-52.

Violle C, Navas M-L, Vile D, Kazakou E, Fortunel C, Hummel I, Garnier E. 2007. Let the concept of trait be functional!. Oikos 116:882-92.
Weiner J. 2004. Allocation, plasticity and allometry in plants. Perspectives in Plant Ecology, Evolution and Systematics 6:207-15.

Westoby M. 1998. A leaf-height-seed (LHS) plant ecology strategy scheme. Plant and Soil 199:213-27.

Wilson PJ, Thompson K, Hodgson JG. 1999. Specific leaf area and leaf dry matter content as alternative predictors of plant strategies. New Phytologist 143:155-62.

Wright IJ, Dong N, Maire V, Prentice IC, Westoby M, Díaz S, Gallagher RV, Jacobs BF, Kooyman R, Law EA, Leishman MR, Niinemets Ü, Reich PB, Sack L, Villar R, Wang H, Wilf P. 2017. Global climatic drivers of leaf size. Science 357:917-21.

Wuest RO, Munkemuller T, Lavergne S, Pollock LJ, Thuiller W. 2018. Integrating correlation between traits improves spatial predictions of plant functional composition. Oikos 127:47281.

Wyka TP, Oleksyn J, Żytkowiak R, Karolewski P, Jagodziński AM, Reich PB. 2012. Responses of leaf structure and photosynthetic properties to intra-canopy light gradients: a common garden test with four broadleaf deciduous angiosperm and seven evergreen conifer tree species. Oecologia 170:11-24.

Zheng S, Li W, Lan Z, Ren H, Wang K. 2015. Functional trait responses to grazing are mediated by soil moisture and plant functional group identity. Scientific Reports 5:18163. 